\title{
A new species of Ischnothyreus (Araneae: Oonopidae) from monsoon rainforest of northern Australia
}

\author{
Karen L. Edward ${ }^{1,2}$ and Mark S. Harvey ${ }^{2,1}$ \\ ${ }^{1}$ School of Animal Biology, University of Western Australia, Crawley, Western Australia 6009, Australia. \\ Email: karen.edward@gmail.com \\ 2 Department of Terrestrial Zoology, Western Australian Museum, Locked Bag 49, \\ Welshpool DC, Western Australia 6986, Australia
}

\begin{abstract}
The first Australian species of the goblin spider genus Ischnothyreus Simon, is described from the Northern Territory, Australia: Ischnothyreus darwini sp. nov. This species is recorded from several different localities within monsoonal forest habitats.
\end{abstract}

\section{INTRODUCTION}

Spiders belonging to the family Oonopidae, commonly known as goblin spiders or dwarf hunting spiders, are incredibly diverse, are known to occur on almost all continents, and have the ability to live in a variety of habitats. They may be found in leaf litter, decaying substratum, under bark and stones, in foliage, and among lower vegetation (Saaristo 2001). Although worldwide in distribution, much of the species diversity can be seen in the tropical areas of the world (Murphy and Murphy 2000).

Particularly abundant throughout the world's tropics and subtropics are species belonging to the genus Ischnothyreus Simon, 1891. Currently only 23 species are described to date (Platnick 2009), including species from Asia and islands in the Indian and Pacific Oceans (Saaristo and Harten 2002; Saaristo 2001; Murphy and Murphy 2000; Tong and Li 2008; Simon 1893; Marples 1955; Oi 1958), and the Caribbean region of the New World (Chickering 1968). The Australian fauna has been largely neglected and at present no species of Ischnothyreus have been described despite large collections present in Australian museums. Ischnothyreus, like other goblin spiders, are haplogyne, usually have six eyes, are considered to be small, free living, nocturnal ground hunters that do not build webs, and generally move using short jerky motions (Ubick 2005; Jocqué and Dippenaar-Schoeman 2006). Species of this genus are more or less scutate and can be characterised by an almost circular eye pattern, heavily sclerotised, tiny male palps with well-separated cymbium and bulbus, and long, stout spines on the first and second legs (Chickering 1968; Saaristo 2001).

During a collecting trip to the Northern Territory,
Australia, several undescribed oonopid species were collected from monsoonal rainforest patches associated with natural springs, creek lines and sandstone outcrops. One of these species belongs to the genus Ischnothyreus and is here described formally as Ischnothyreus darwini in honour of Charles Darwin in commemoration of the $150^{\text {th }}$ anniversary of his famous publication $O n$ the Origin of Species, and the $200^{\text {th }}$ anniversary of his birth in 1809. Ischnothyreus darwini represents the first species of Ischnothyreus to be described from Australia and forms part of a large-scale revision of the genus associated with a Plantetary Biodiversity Inventory Project that aims to document the worldwide diversity of the spider family Oonopidae (http://research.amnh.org/oonopidae).

\section{MATERIALS AND METHODS}

The majority of specimens were collected during an expedition to the Northern Territory to collect oonopid spiders specimens were most collected by hand using a soil sieve ( $5 \mathrm{~mm}$ grid size) and collecting tray to sieve moist rainforest leaf litter. Other museum specimens available were collected using berlese funnels in the late 1970s.

Specimens examined in this study are lodged in the Northern Territory Museum, Darwin (NTM), the Queensland Museum, Brisbane (QM) and the Western Australian Museum, Perth (WAM). Whole specimens were examined using Leica MZ16A and Olympus SZX7 binocular microscopes. Digital images were composed from multiple images taken with a Leica DFC 500 digital camera attached to the Leica MZ16A using the software program AutoMontage Pro version 5.02 (p). Temporary slide mounts were made by placing specimens in a $20 \%$ lactic acid/glycerol solution or clove oil at room 
temperature for at least 24 hours and mounting them on microscope slides with $10 \mathrm{~mm}$ cover slips supported by small sections of $0.25 \mathrm{~mm}$ or $0.5 \mathrm{~mm}$ diameter nylon fishing line. Preparations were examined with an Olympus BX41 compound microscope and illustrated with the use of a drawing tube. After study specimens were returned to $75 \%$ ethanol and dissected parts placed in $12 \times 3 \mathrm{~mm}$ glass genitalia micovials (BioQuip Products, Inc.).

Measurements were taken at the highest possible magnification using an ocular graticule, and are in millimetres $(\mathrm{mm})$. Leg spines were documented by dividing each leg segment into four aspects: prolateral $(\mathrm{p})$, retrolateral $(\mathrm{r})$, ventral $(\mathrm{v})$ and dorsal (d) and dividing each aspect into basal, middle, and distal sections separated by a dash: (eg. p1-1-0). The species description of the legs includes only segments and positions where spines were present. Colour was described from freshly collected specimens preserved in $75 \%$ ethanol. Descriptions were generated with the aid of the PBI descriptive Goblin Spider database and modified where appropriate (http://research.amnh.org/oonopidae).

The following abbreviations were used in the manuscript: ALE, anterior lateral eyes; PLE, posterior lateral eyes; PME, posterior median eyes.

\section{SYSTEMATICS}

\section{Family Oonopidae Simon, 1890}

Genus Ischnothyreus Simon, 1891

Ischnaspis Simon, 1891: 562 (preoccupied by Ischnaspis Douglas, 1887; Hemiptera).

Ischnothyreus Simon, 1893: 298 (replacement name for Ischnaspis)

\section{Type species}

Ischnaspis peltifer Simon, 1891, by original designation.

\section{Diagnosis}

Ischnothryeus are small to medium sized (1.4-3.5) scutate oonopids. Ischnothyreus species differ from all other oonopid genera by a combination of the following characters (Chickering 1968; Saaristo 2001; Saaristo and Harten 2002): legs I and II with strong spines on femora, tibiae, and metatarsi. Eyes relatively large, mostly touching each other, forming a ring. Male palps heavily sclerotised with clearly separated cymbium and bulb. Bulb usually elongated and gradually tapering to an obtusely bent, relatively stout embolic part. Female genitalia with a median convoluted duct starting from the epigastric furrow, winding posteriorly to end in a funnel-like atrium. The body and appendages of Ischnothyreus species are only moderately chitinized with the exception of the male palps which are usually dark and heavily sclerotised.

\section{Ischnothyreus darwini sp nov.}

Figures 1-11

\section{Material examined}

Holotype

Australia: Northern Territory: $\delta$, Mary River National Park, Bryan Creek Monsoon Rainforest Patch, $12^{\circ} 39^{\prime} 40^{\prime \prime} \mathrm{S}, 131^{\circ} 46^{\prime} 55^{\prime \prime} \mathrm{E}, 25$ April 2008, in rainforest leaf litter under rotting log, K. Edward and P. Cullen (NTM A004398, PBI-OON 00005889)

\section{Paratypes}

Australia: Northern Territory: allotype + , same data as holotype (NTM A004399, PBIOON 00005892); 2 万, 1 ㅇ, 1 juvenile, same data as holotype (NTM A004400, PBI-OON 0000 5968); 1 त, 1 , same data as holotype (WAM T85191, PBI-OON 00025692 \& 00025693); 1 ภ, 1 ९, 4 juveniles, Howard Springs Nature Park, forest walk trail, $12^{\circ} 27^{\prime} 27^{\prime \prime} \mathrm{S}$, $131^{\circ} 03^{\prime} 07^{\prime \prime}$ E, 9 May 2008, lowland monsoon vineforest, leaf litter at edge of spring fed pool, K. Edward and P. Cullen (NTM A004401, PBI-OON 00005969); 1 ก, 1 , Howard Springs Nature Park, forest walk trail, $12^{\circ} 27^{\prime} 27^{\prime \prime} \mathrm{S}, 131^{\circ} 03^{\prime} 07^{\prime \prime} \mathrm{E}, 9$ May 2008, lowland monsoon vine-forest, leaf litter at edge of spring fed pool, K. Edward and P. Cullen (WAM T85192, PBI-OON 00025703 \& 00025704);1우, Litchfield National Park, Wangi Falls, $13^{\circ} 09^{\prime} 10^{\prime \prime}$, $130^{\circ} 41^{\prime} 04^{\prime \prime} \mathrm{E}, 7$ May 2008; leaf litter next to spring fed waterfall below Carpentaria palms and ferns, K. Edward and P. Cullen (NTM A004402, PBI-OON 00025702); 1 ภ, 3 ㅇ, 2 juveniles, Umbrawarra Gorge Nature Park, gorge walk, $13^{\circ} 57^{\prime} 58^{\prime \prime} \mathrm{S}, 131^{\circ} 41^{\prime} 38^{\prime \prime} \mathrm{E}$, 3 May 2008, spring fed Melaleuca creek line, moist humus and leaf litter, K. Edward and P. Cullen (NTM A004403, PBI-OON 00025699 \& 00025700); 2 , Kakadu National Park, South Alligator River area, Gu-ngarre monsoon forest walk, $12^{\circ} 40^{\prime} 40^{\prime \prime} \mathrm{S}$, $132^{\circ} 28^{\prime} 56^{\prime \prime}$ E, 24 April 2008, rainforest leaf litter, K. Edward and P. Cullen (NTM A004404, PBIOON 00005970); 1 ㅇ, Kakadu National Park, South Alligator River area, Gu-ngarre monsoon forest walk, $12^{\circ} 40^{\prime} 40^{\prime \prime} \mathrm{S}, 132^{\circ} 28^{\prime} 56^{\prime \prime} \mathrm{E}, 24$ April 2008, rainforest leaf litter, K. Edward and P. Cullen (NTM A004405, PBI-OON 00025691); 3 के, 1 + 5 juveniles, Kakadu National Park, Mary River Area, Boulder

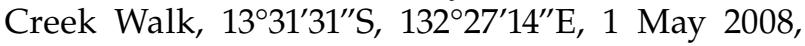
small monsoonal rainforest patch down spring fed gully, moist humus and leaf litter, K. Edward and P. Cullen (NTM A004406, PBI-OON 00005971); 1 d, 1 ㅇ, Kakadu National Park, Mary River Area, 

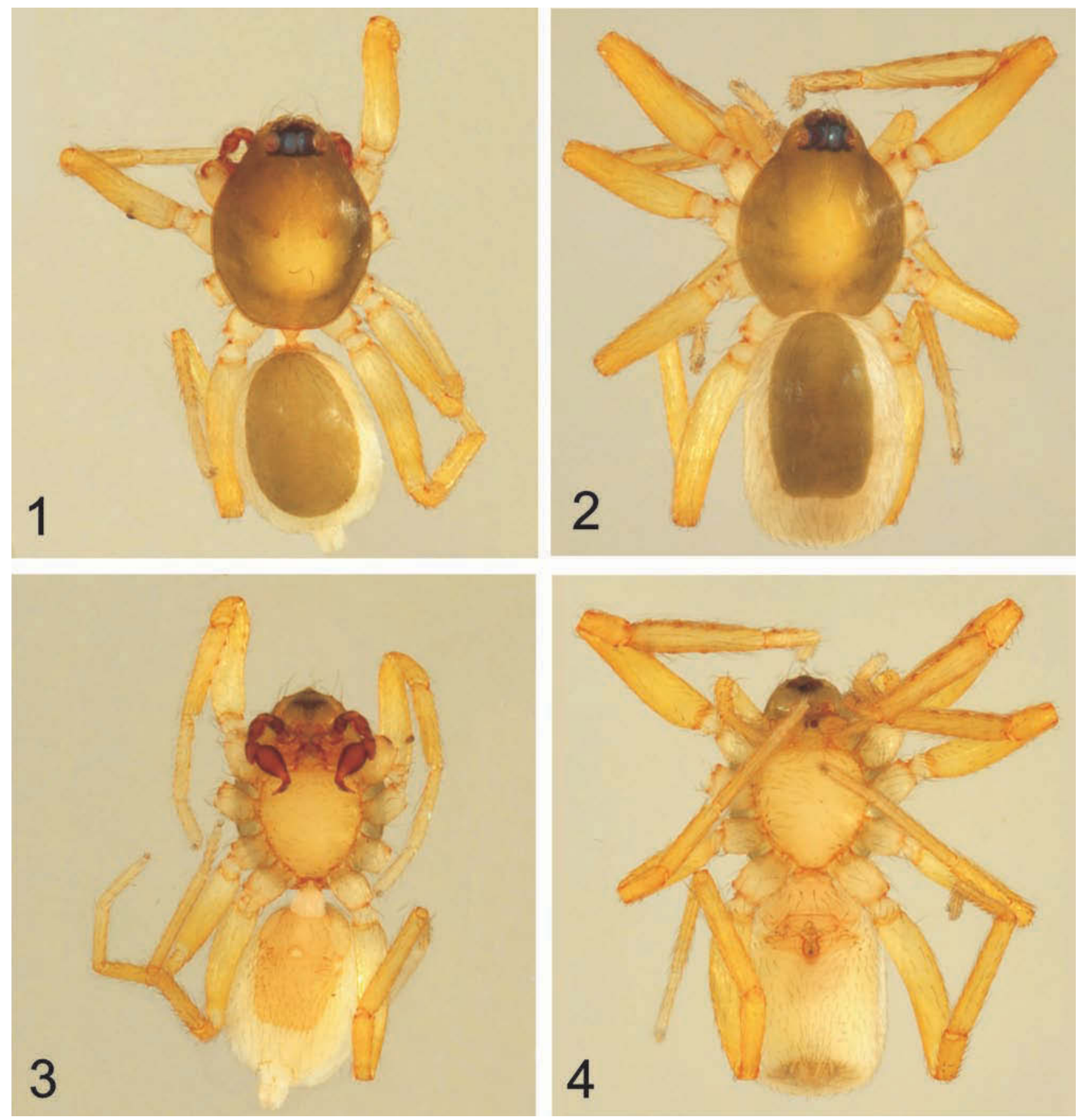

Figures 1-4 Ischnothyreus darwini, sp. nov., holotype male and allotype female from Mary River National Park, Northern Territory: 1, male habitus, dorsal view; 2 , female habitus, dorsal view; 3 , male habitus, ventral view; 4 , female habitus, ventral view.

Boulder Creek Walk, 1331'31"S, 132 $27^{\prime} 14^{\prime \prime} \mathrm{E}, 1$ May 2008, small monsoonal rainforest patch down spring fed gully, moist humus and leaf litter, K. Edward and P. Cullen (WAM T85193, PBI-OON 00025695 \& 00025696); 2 o, 3 ㅇ, 1 juvenile, Kakadu National Park, Mary River Area, natural spring

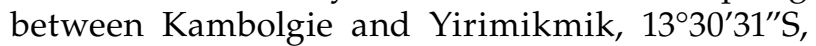
$132^{\circ} 25^{\prime} 31^{\prime \prime} \mathrm{E}, 2$ May 2008, spring fed monsoonal vegetation along moist gully and flowing creek, thick leaf litter and peaty humus, K. Edward and P. Cullen (NTM A004407, PBI-OON 00025697 \&
00025698).

Other material examined

Australia: Northern Territory: $1 \hat{O}$, South Alligator Inn, $12^{\circ} 40^{\prime} \mathrm{S}, 132^{\circ} 30^{\prime} \mathrm{E}, 1$ November 1979 , rainforest, under logs, R. Raven (QM S16128; PBIOON 00005885); 1 Oे, 2 ㅇ, South Alligator Inn, $12^{\circ} 40^{\prime} \mathrm{S}, 132^{\circ} 30^{\prime} \mathrm{E}, 10$ November 1979 , rainforest, Berlesate trap, R. Raven (QM S16129; PBI-OON 00005884); 1 ㅇ, Radon Creek, Mt Brockman, 

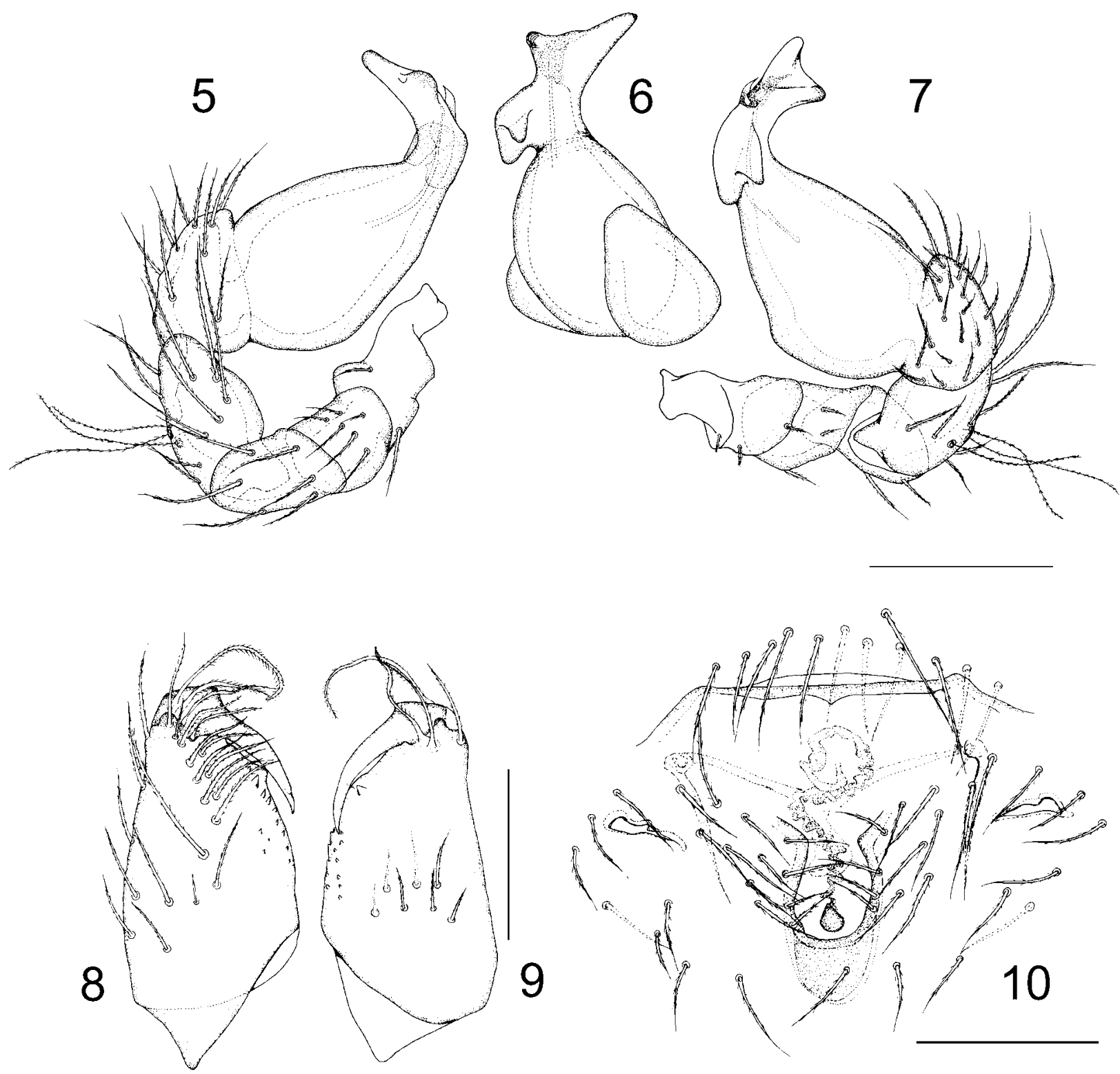

Figures 5-10 Ischnothyreus darwini, sp. nov., male holotype from Mary River National Park, Northern Territory (PBIOON 00005889): 5, left male palp, prolateral view; 6, left male palpal bulb, dorsal view; 7 , left male palp, retrolateral view; 8 , left male chelicerae, anterior view; 9, left male chelicerae, posterior view. Female allotype (PBI-OON 00005892): 10, genital area of female, ventral view. Scale lines $=0.1 \mathrm{~mm}$.

$12^{\circ} 45^{\prime}$ S, $132^{\circ} 53^{\prime} \mathrm{E}, 14$ November 1979 , dry rainforest, Berlesate trap, R. Raven (QM S16120; PBI-OON 00005992); 1 , Radon Creek, Mt Brockman, $12^{\circ} 45^{\prime} \mathrm{S}, 132^{\circ} 53^{\prime} \mathrm{E}, 14$ November 1979 , wet rainforest, Berlesate trap, G.B. Monteith (QM S16117; PBIOON 00005965); 1 jे, Radon Creek, Mt Brockman, $12^{\circ} 45^{\prime} \mathrm{S}, 132^{\circ} 53^{\prime} \mathrm{E}, 14$ November 1979, dry rainforest, Berlesate trap, G.B. Monteith (QM S16098; PBIOON 00005966); 2 juveniles, Kapalga, North Point, $12^{\circ} 25^{\prime}$ S, $132^{\circ} 22^{\prime} \mathrm{E}, 11$ November 1979, Berlesate trap, R. Raven (QM S79316; PBI-OON 00005967).

\section{Diagnosis}

The male of I. darwini can easily be recognised by the unique shape of the embolic region of the papal bulb which divides roughly into 2 lobes (Figures 5-7). Males do not have a distinct knob or modification on the basal part of the fang, but it is slightly flattened. The chelicera have a series of denticles along the fang groove but are otherwise unmodified (Figures 8, 9). The female epigynum region has a dark coloured, thin, convoluted duct that ends posteriorly in an omega-shaped atrium that is darkly sclerotised (Figure 10).

\section{Description}

\section{Holotype male}

Cephalothorax: carapace olive-green, with light brown egg-shaped patches behind eyes, ovoid in 
dorsal view, pars cephalica strongly elevated in lateral view, anteriorly narrowed to between 0.5 and 0.75 times its maximum width, anterolateral corners without extension or projections, surface of elevated portion of pars cephalica smooth to finely reticulate, sides strongly reticulate, fovea absent; non-marginal pars cephalica setae present, scattered; non-marginal pars thoracica setae absent; marginal setae needle-like. Clypeus straight in front view, low, ALE separated from edge of carapace by less than their radius. Eyes posterior eye row from above very slightly procurved but mostly straight, ALE largest, PME ovoid, PLE circular; ALE touching, ALE-PLE touching, PLEPME touching. Sternum as long as wide, yellow, without radial furrows between coxae I-II, II-III, III-IV, posterior margin not extending posteriorly of coxae IV, distance between coxae approximately equal; setae sparse. Chelicerae, endites and labium yellow, directed medially. Chelicerae: base of fang flat and straight but without prominent process or modification; promargin of chelicerae with small tooth-like projections (denticles). Labium elongated hexagon, not fused to sternum, anterior margin indented at middle. Endites distally not excavated, posteromedian part unmodified, same as sternum in sclerotization.

Abdomen: ovoid, rounded posteriorly; dorsum soft portions white. Pedicel tube short, scutum extending far dorsal of pedicel. Dorsal scutum weakly sclerotized, olive-green, covering more than $3 / 4$ of abdomen, more than $1 / 2$ to most of abdomen width, not fused to epigastric scutum, middle surface smooth, sides smooth. Epigastric scutum surrounding pedicel, not protruding, small lateral sclerites absent. Postepigastric scutum yellow, almost rectangular, covering about $2 / 3$ of abdominal length, fused to epigastric scutum, anterior margin unmodified, without posteriorly directed lateral apodemes.

Legs: pale orange; patella plus tibia I near as long as carapace; femur IV not thickened, similar size as femora I-III; Leg I spines present, longer than leg segment width, formula: femur $\mathrm{p} 0-0-2$; tibia $\mathrm{p} 2-2-$

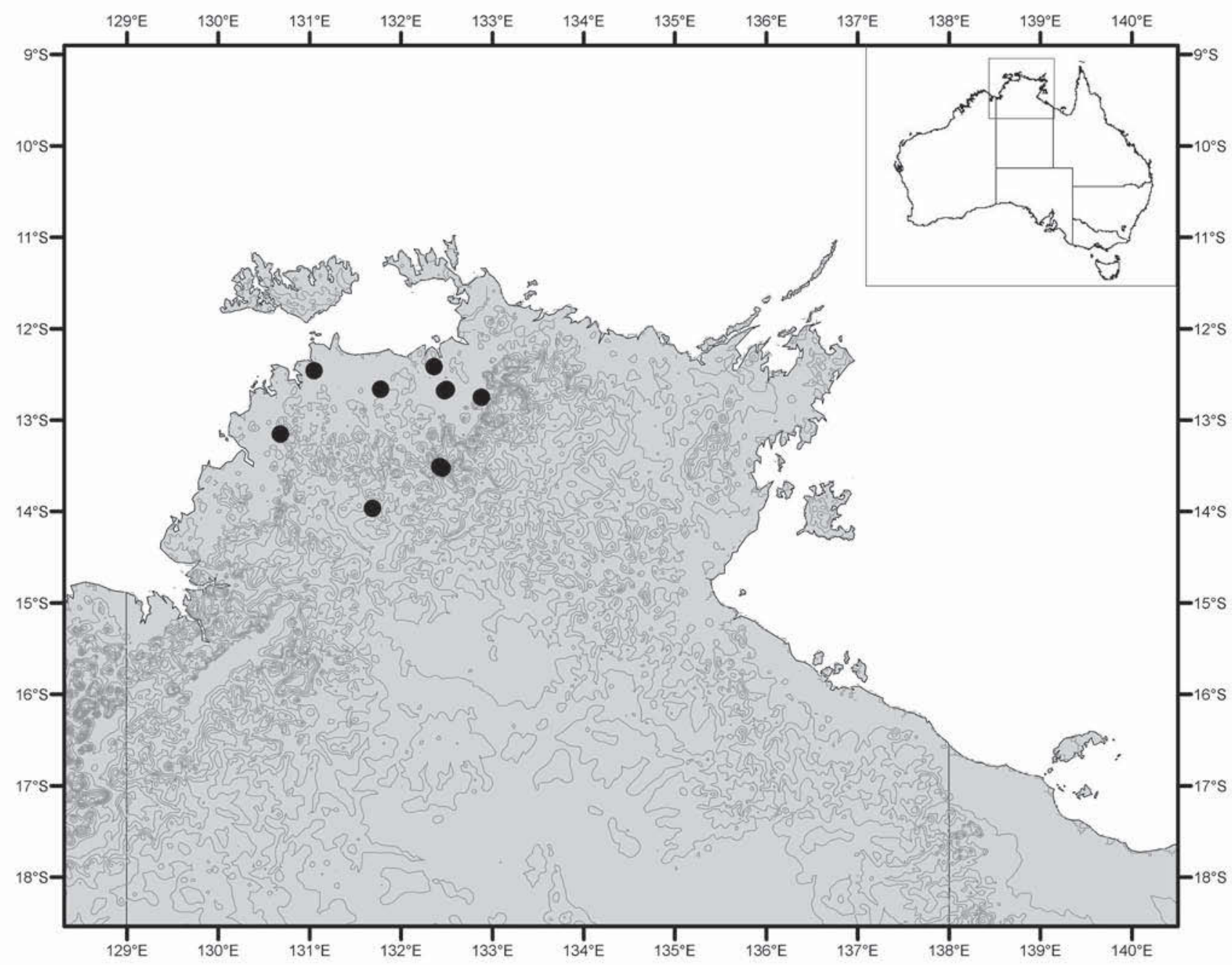

Figure 11 Distribution of Ischnothyreus darwini, sp. nov. (•) in the Northern Territory, Australia. 
0 , v2-2-0; metatarsus p1-1-0, v1-1-0; leg II spines present, longer than leg segment width, formula: femur p0-0-2; tibia p2-1-1, v2-1-1; metatarsus p11-0, v1-1-0; legs III - IV spines absent. Trichobothria dorsally positioned; leg I-IV with 1 basal, 2 distal tricobothria on tibia, 1 distal tricobothria on metatarsus.

Palp: proximal segments dark red-brown; embolus dark; trochanter with ventral projection; femur shorter than trochanter; patella about as long as femur; tibia with 3 medial tricobothrium on dorsal surface; cymbium dark red-brown, fused with bulb but with clearly defined seam between, with distal patch of setae; bulb dark redbrown, more than 2 times as long as cymbium, stout. Embolic part of palpal bulb divided into two distinct processes or lobes, each slightly bifurcated with rounded tips. Short, thin sperm duct visible beneath chitin starting posterior to obtusely bent tip. Duct appears to end at darkly coloured region on ventral surface of medial lobe above a small transparent triangular pointed structure.

Genitalia: epigastric region with large rounded sperm pore situated at level of anterior spiracles, unmodified.

\section{Allotype female}

As for male except as follows:

Cephalothorax: carapace without any pattern, broadly oval in dorsal view, pars cephalica slightly elevated in lateral view, anteriorly narrowed to 0.49 times its maximum width or less, surface of elevated portion of pars cephalica smooth; nonmarginal pars cephalica setae dark; marginal setae dark.

Abdomen: cylindrical, rounded posteriorly; dorsum soft portions pale. Pedicel scutum not extending far dorsal of pedicel. Dorsal scutum covering $1 / 2$ to $3 / 4$ of abdomen, between $1 / 4$ and $1 / 2$ abdomen width, almost rectangular at posterior end. Epigastric scutum without lateral joints. Postepigastric scutum pale orange, widely hexagonal, covering less than $1 / 3$ of abdominal length, not fused to epigastric scutum. Dorsum setae serrate. Epigastric area frontal setae thickened, serrate. Postepigastric area setae serrate. Dense patch of setae anterior to spinnerets present.

Legs: female palp tarsus unmodified. Leg I spines present, longer than leg segment width, formula: femur p0-0-2; tibia p2-2-0, r2-2-0; metatarsus p1-1-0, r1-1-0; leg II spines present, longer than leg segment width, formula: femur $\mathrm{p} 0-0-1$; tibia $\mathrm{p} 2--$ 1-0, r2-1-0; metatarsus p1-1-0, r1-1-0; t; legs III -IV spines absent. Trichobothria dorsally positioned.

Genitalia: postepigastric scutum widely hexagonal. A thin, darkly coloured convoluted tube visible through cuticle, originating posterior to middle of epigastic furrow and extending to a darkly coloured tear-drop shaped process in base of omega-shaped atrium or depression. Omegashaped depression heavily sclerotised posteriorly. Posteriorly directed apodemes present.

\section{Dimensions (mm)}

Holotype $\widehat{o}$ (allotype )): total length 1.26 (1.34). Carapace length $0.66(0.64)$, width $0.50(0.53)$, height 0.23 (0.24). Eye group width 0.19 (0.19). Sternum length $0.36(0.38)$, width $0.34(0.37)$. Opisthosoma length 0.55 (0.76), width 0.38 (0.49). Pedipalp: femur 0.06 , patella 0.07 , tibia 0.09 , tarsus 0.2 , total 0.42 . Leg I: femur 0.46/0.14 (0.51/0.16), patella $0.19(0.23)$, tibia $0.38(0.48)$, metatarsus $0.30(0.36)$, tarsus $0.20(0.21)$, total 1.53 (1.78). Leg II: femur 0.42/0.13 (0.47/0.15), patella $0.19(0.21)$, tibia $0.33(0.40)$, metatarsus 0.29 , (0.35), tarsus $0.20(0.21)$, total 1.43 (1.64). Leg III: femur $0.38 / 0.11(0.37 / 0.12)$, patella $0.16(0.21)$, tibia $0.24(0.30)$, metatarsus $0.27(0.30)$, tarsus $0.20(0.18)$, total 1.24 (1.35). Leg IV: femur 0.54/0.13 (0.60/0.13), patella $0.20(0.27)$, tibia $0.33(0.48)$, metatarsus 0.34 (0.31), tarsus $0.16(0.26)$, total $1.56(1.92)$.

\section{Remarks}

Ischnothyreus darwini is currently only known from the north-western region of the Northern Territory ranging from Darwin, east to Kakadu National Park, and south to Umbrawarra Gorge Nature Park (Figure 11). However, further collecting in Arnhemland may uncover new populations of this particular species. Ischnothyreus darwini is known to occur in areas of monsoonal rainforest, associated with vine thickets, sandstone outcrops, creek lines and natural springs and was collected from moist leaf litter and fallen logs.

\section{Etymology}

This specific epithet is a patronym in honour of Charles Darwin (1809-1882), on the $150^{\text {th }}$ anniversary of his influential publication $O n$ the Origin of Species, and the $200^{\text {th }}$ anniversary of his birth.

\section{ACKNOWLEDGEMENTS}

This research contributed to a Doctor of Philosophy degree for the senior author at the University of Western Australia, and was funded by the School of Animal Biology (UWA) and the National Science Foundation of America (NSF) through the Planetary Biodiversity Inventory project "The Megadiverse, Microdistributed Spider Family Oonopidae" (grant DEB-0613754). We thank Dr Norman I. Platnick for his support and the facilitation of this project and Professor Dale Roberts for supervision of this project. The background work to this project was supported by 
a grant to M. Harvey by the Australian Biological Resources Study. Many thanks are due to Patrick Cullen who assisted in the collection of specimens from the Northern Territory used in this study.

\section{REFERENCES}

Chickering, A.M. (1968). The genus Ischnothyreus (Araneae, Oonopidae) in Central America and the West Indies. Psyche 75: 77-86.

Jocqué, R. and Dippenaar-Schoeman, A. (2006). Spider families of the world. Musée Royal de l'Afrique Centrale: Tervuren.

Marples, B.J. (1955). Spiders from Western Samoa. Journal of the Linnean Society of London, Zoology 42: 453-504.

Murphy, F. and Murphy, J.A. (2000). An introduction to the spiders of south east Asia. Malaysian Nature Society: Kuala Lumpur.

Oi, R. (1958). [Three new species of the six eyed spider]. Acta Arachnologica 15: 31-36.

Platnick, N.I. (2009). The World Spider Catalog, Version
9.5. American Museum of Natural History, New York. http: / / research.amnh.org/entomology/spiders / catalog/index.html (accessed March 2009).

Saaristo, M.I. (2001). Dwarf hunting spiders or Oonopidae (Arachnida, Araneae) of the Seychelles. Insect Systematics and Evolution 32: 307-358.

Saaristo, M.I. and Harten, A. van (2002). The oonopid spiders (Arachnida: Araneae: Oonopidae) of Socotra, Yemen. Fauna of Arabia 19: 311-319.

Simon, E. (1893). Arachnides In Voyage de M.E. Simon auz îles Philippines (Mars et Avril 1890) 6e Mémoire. Annales de la Société Entomologique de France 62: 65-80.

Tong, Y.F. and Li, S. (2008). The oonopid spiders (Araneae: Oonopidae), from Hainan Island, China. Raffles Bulletin of Zoology 56: 55-66.

Ubick, D. (2005). Oonopidae (pp. 185-188). In: Ubick, D., Paquin, P., Cushing, P.E. and Roth, V. (eds), Spiders of North America: an identifcation manual, American Arachnological Society: Denver.

Manuscript received 27 March 2009: accepted 28 July 2009. 